\title{
Influência de atributos físico-químicos do solo e do tempo de adoção da colheita mecanizada da cana crua no teor e estoque de carbono orgânico do solo
}

\author{
Cristiane A. de Oliveira (IC), Mara de A. Marinho (PQ), Michender W. M. Pereira (PG)
}

\section{Resumo}

O objetivo deste trabalho foi quantificar o conteúdo e estoque de carbono orgânico do solo (COS e ECS) após cinco (5a) e dez (10a) anos de colheita mecanizada da cana crua e estudar as correlações com atributos físico-químicos do solo. Foram descritos e amostrados perfis de Latossolo Vermelho Distrófico, até $130 \mathrm{~cm}$ de profundidade, sendo dois de textura argilosa (LVda, P1-5a e P2-10a) e dois de textura média (LVdm, P3-5a e P4-10a). Obteve-se que teor e estoque de COS são influenciados pelo tempo de adoção da colheita mecanizada da cana crua, mas o efeito da qualidade estrutural do solo pode ter um peso ainda maior na conservação do carbono. Atributos que se correlacionaram linearmente com o COS foram teor de fósforo, CTC e porosidade total do solo.

Palavras Chave: Matéria Orgânica, Porosidade do Solo, Latossolo Vermelho.

\section{Introducão}

O revolvimento do solo no preparo para cultivo ocasiona um aumento da superfície de contato do solo com o ar, expondo a matéria orgânica aos microrganismos decompositores, o que contribui para o decréscimo do teor de carbono ao longo dos anos ${ }^{1}$. Tendo em vista que a adoção da colheita mecanizada da cana-de-açúcar é um fato relativamente novo, mas crescente no Estado de São Paulo, é essencial conhecer a relação dos atributos físico-químicos do solo, juntamente com o efeito temporal da colheita mecanizada da cana crua no teor e estoque de COS.

Esta pesquisa objetivou quantificar o conteúdo e estoque de COS em solos cultivados com canade-açúcar e estudar as correlações com atributos físico-químicos do solo.

\section{Resultados e Discussão}

Foram analisados dois Latossolos Vermelhos Distróficos cultivados com cana-de-açúcar, sendo um de textura argilosa (LVda) e outro de textura média (LVdm). Em cada tipo de solo, foram amostrados dois perfis, até $130 \mathrm{~cm}$ de profundidade, estando um submetido à colheita mecanizada da cana crua há 5 anos (5a) e o outro há 10 anos (10a).

No LVda, o COS do perfil 1 (P1-5a) é maior do que o COS do perfil 2 (P2-10a), resultado não esperado, mas explicado pela degradação observada da estrutura do solo na área de 10 anos (P2), principalmente relacionada com compactação do solo e consequente baixa macroporosidade nos horizontes Ap2 e BA ${ }^{2}$.

No LVdm, como esperado, o COS é maior na área no perfil 4 sob colheita mecanizada há 10 anos (P4-10a), comparado ao COS do perfil 3 (P3-5a). O estoque de carbono no solo (ECS) apresentou o mesmo comportamento do COS, tendo sido calculados os seguintes estoques na profundidade de 0-130 cm: P1, 233,02 $\mathrm{Mg} \mathrm{ha}^{-1}$; P2, 179,38 Mg ha ${ }^{-1}$; P3, 202,17 $\mathrm{Mg} \mathrm{ha}^{-1}$; e, P4, 253,16 $\mathrm{Mg} \mathrm{ha}^{-1}$. Correlações lineares significativas foram observadas entre COS e porosidade total do solo, teor de fósforo e capacidade de troca de cátions. Tais correlações podem explicar maiores estoques em P1 (argiloso) comparado a P3 (textura média) e menor ECS em P2 em relação a P4. A degradação da estrutura de P2 (porosidade mais baixa) afeta o funcionamento do solo e expõe a importância da funcionalidade da estrutura.

\section{Conclusões}

O teor e estoque de COS foram influenciados pelo tempo de adoção da colheita mecanizada da cana crua e pela qualidade estrutural do solo. $\mathrm{O}$ teor de fósforo, a CTC e a porosidade total do solo correlacionaram-se linearmente com o teor de COS neste estudo.

\section{Agradecimentos}

Agradecimentos ao PIBIC/SAE, pela bolsa de iniciação científica concedida ao primeiro autor.

\footnotetext{
${ }^{1}$ Souza, H.; Marcelo, A.; Centurion, J. Revista Ciência Agronômica, 2012, 43: 658-663.

${ }^{2}$ Pereira, M. W. M. Dissertação de Mestrado, 2014, Faculdade de Engenharia Agrícola - Universidade Estadual de Campinas. 111p.
} 